SRNL-STI-2011-00364

\title{
ASSESSMENT OF THE POTENTIAL FOR HYDROGEN GENERATION DURING GROUTING OPERATIONS IN C-REACTOR DISASSEMBLY BASIN
}

\author{
B. J. WIERSMA \\ Savannah River National Laboratory \\ Materials Science and Technology Directorate
}

Publication Date: July 2011

This document was prepared in conjunction with work accomplished under Contract No. DEAC09-08SR22470 with the U. S. Department of Energy

\section{We Put Science To Work}

The Savannah River National Laboratory is managed and operated for the U.S. Department of Energy by

SAVANNAH RIVER NUCLEAR SOLUTIONS, LLC AIKEN, SC USA 29808 -SRNL.DOE.GOV 
SRNL-STT-2011-00364

\section{DISCLAIMER}

This report was prepared under an agreement with and funded by the U. S. Government. Neither the U. S. Government or its employees, nor any of its contractors, subcontractors or their employees, makes any express or implied: 1. warranty or assumes any legal liability for the accuracy, completeness, or for the use of results of such use of any information, product or process disclosed; or 2. representation that such use or results of such use would not infringe privately owned rights; or 3 . endorsement or recommendation of any specifically identified commercial product, process or service. Any views and opinions of authors expressed in this work do not necessarily state or reflect those of the United States Government, or its contractors, or subcontractors. 
SRNL-STI-2011-00364

DOCUMENT: SRNS-STI-2011-00364

TITLE: Assessment of the Potential for Hydrogen Generation During Grouting Operations in C-Reactor Disassembly Basin

\section{APPROVALS}

Date:

B. J. Wiersma, Author

Materials Performance and Corrosion Technology

Materials Science and Technology

Date:

B. Garcia-Diaz, Technical Reviewer

Materials Performance and Corrosion Technology

Materials Science and Technology Directorate

K. E. Zeigler, Manager

Materials Performance and Corrosion Technology

Materials Science and Technology Directorate

J. K. Blankenship, Customer

Date:

SDD Decommisioning Engineering 


\section{Table of Contents}

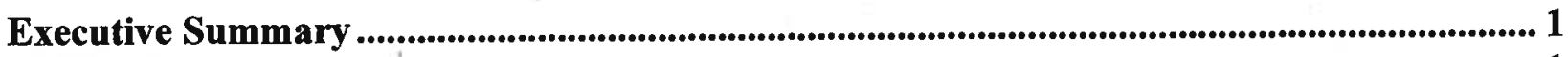

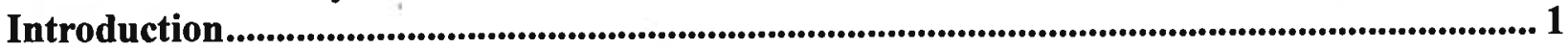

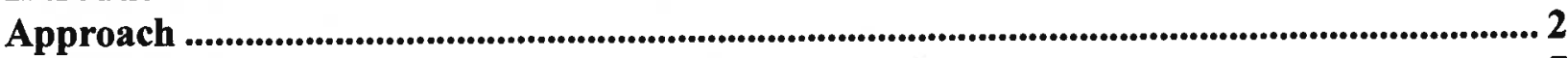

Determination of Cross-Sectional Area of the Basin .................................................................... 7

Determination of Actual Aluminum Surface Area ........................................................................ 7

Determination of Minimum Ventilation Rate...............................................7

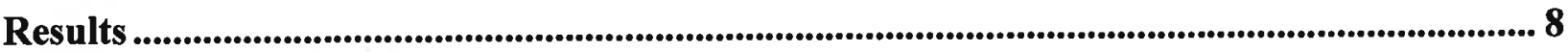

Conclusions and Recommendations ...................................................................................... 10

References ............................................................................................................................... 18

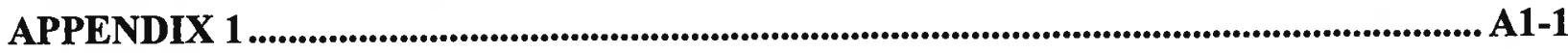

APPENDIX 2 ........................................................................A2-1

\section{List of Figures}

Figure 1. Universal Sleeve Housing located in the Vertical Tube Storage region of the basin.. ................................................................................................................................................ 2

Figure 2. Aluminum Areal Density Ratio for Flammable Condition in Grout.................11

Figure 3. Aluminum Areal Density Ratio for Flammable Condition in $\mathrm{Ca}(\mathbf{O H})_{2} \ldots . . . . . . . .12$ Figure 4. Time dependence of temperature at the center of a mortar form for various cementitious materials. ................................................................................................................... 13

Figure 5. Assessment of Flammability Condition for Grout at $50{ }^{\circ} \mathrm{C} . \ldots \ldots \ldots . . . . . . . . . . . . .14$

Figure 6. Assessment of Flammability Condition for $\mathrm{Ca}(\mathrm{OH})_{2}$ at $40{ }^{\circ} \mathrm{C}$.......................15 Figure 7. Assessment of Hydrogen Accumulation as a Function of Building Ventilation for

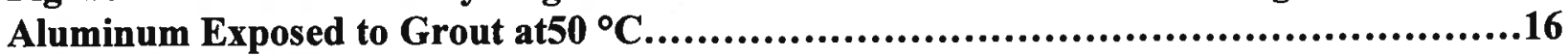
Figure 8. Assessment of Hydrogen Accumulation as a Function of Building Ventilation for

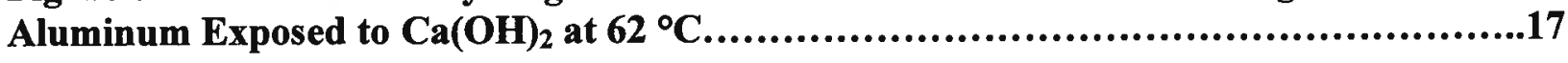

List of Tables

Table 1. Cross-Sectional Area of the Disassembly Basin Regions and Aluminum Component Surface Area......................................................................7 


\section{Assessment of the Potential for Hydrogen Generation During Grouting Operations in C-Reactor Disassembly Basin}

\section{Executive Summary}

C-reactor disassembly basin is being prepared for deactivation and decommissioning (D\&D). D\&D activities will consist primarily of immobilizing contaminated scrap components and structures in a grout-like formulation. The disassembly basin will be the first area of the $\mathrm{C}$-reactor building that will be immobilized. The scrap components contain aluminum alloy materials. Any aluminum will corrode very rapidly when it comes in contact with the very alkaline grout $(\mathrm{pH}>13)$, and as a result would produce hydrogen gas. To address this potential deflagration/explosion hazard, Savannah River National Laboratory (SRNL) reviewed and evaluated existing experimental and analytical studies of this issue to determine if any process constraints are necessary.

The risk of accumulation of a flammable mixture of hydrogen above the surface of the water during the injection of grout into the C-reactor disassembly area is low if the assessment of the aluminum surface area is reliable. Conservative calculations estimate that there is insufficient aluminum present in the basin areas to result in significant hydrogen accumulation in this local region. The minimum safety margin (or factor) on a $60 \% \mathrm{LFL}$ criterion for a local region of the basin (i.e., Horizontal Tube Storage) was greater than 3. Calculations also demonstrated that a flammable situation in the vapor space above the basin is unlikely. Although these calculations are conservative, there are some measures that may be taken to further minimize the risk of developing a flammable condition during grouting operations.

1. Minimize the initial temperature of the water and grout as much as practical. Lower temperatures will mean lower hydrogen generation rates.

2. Ventilate the building above the basin rim as much as practical (e.g., leave doors open and operate fans) to further disperse hydrogen.

3. Minimize interruptions to the grout placement process as much as possible. Interruptions will result in higher water temperatures and hence higher hydrogen evolution rates.

4. Grout areas where the actual areal density ratios are the highest (e.g., Horizontal Tube Storage and Vertical Tube Storage) first. Thus, the areas that will produce the highest volume of hydrogen will have the maximum building volume in which to expand.

\section{Introduction}

The C-Reactor building is being prepared for deactivation and decommissioning (D\&D). D\&D activities will consist primarily of immobilizing contaminated components and structures in a grout-like formulation. The disassembly basin will be the first area of the $\mathrm{C}$-reactor building that will be immobilized. The disassembly basin may be divided into 
six primary areas: Horizontal Tube Storage, Vertical Tube Storage, Dry Cave, D\&E Canal, Machine Basin (including the Monitor Basin) and the Transfer Station.

Currently contaminated scrap components from the reactor and basin are scattered across the basin floor in a random fashion (see Figure 1). Furthermore, the basin is filled with water to within 79 inches of the 0'-0" elevation. The current plan is to inject grout beneath the water in order to immobilize the scrap components and any sludge material on the basin floor.

The scrap components contain aluminum alloy materials [1]. Aluminum corrodes very rapidly when it comes in contact with the very alkaline grout $(\mathrm{pH}>13)$, and as a result will produce hydrogen gas [2]. If the areal density ratio (i.e. surface area of aluminum to cross-sectional area of basin floor) exceeds a critical value, the volume percentage of hydrogen at the water surface could exceed the lower flammability limit (i.e., 4 vol.\%). To address this potential deflagration/explosion hazard, Savannah River National Laboratory (SRNL) reviewed and evaluated existing experimental and analytical studies of this issue to determine if any process constraints are necessary.

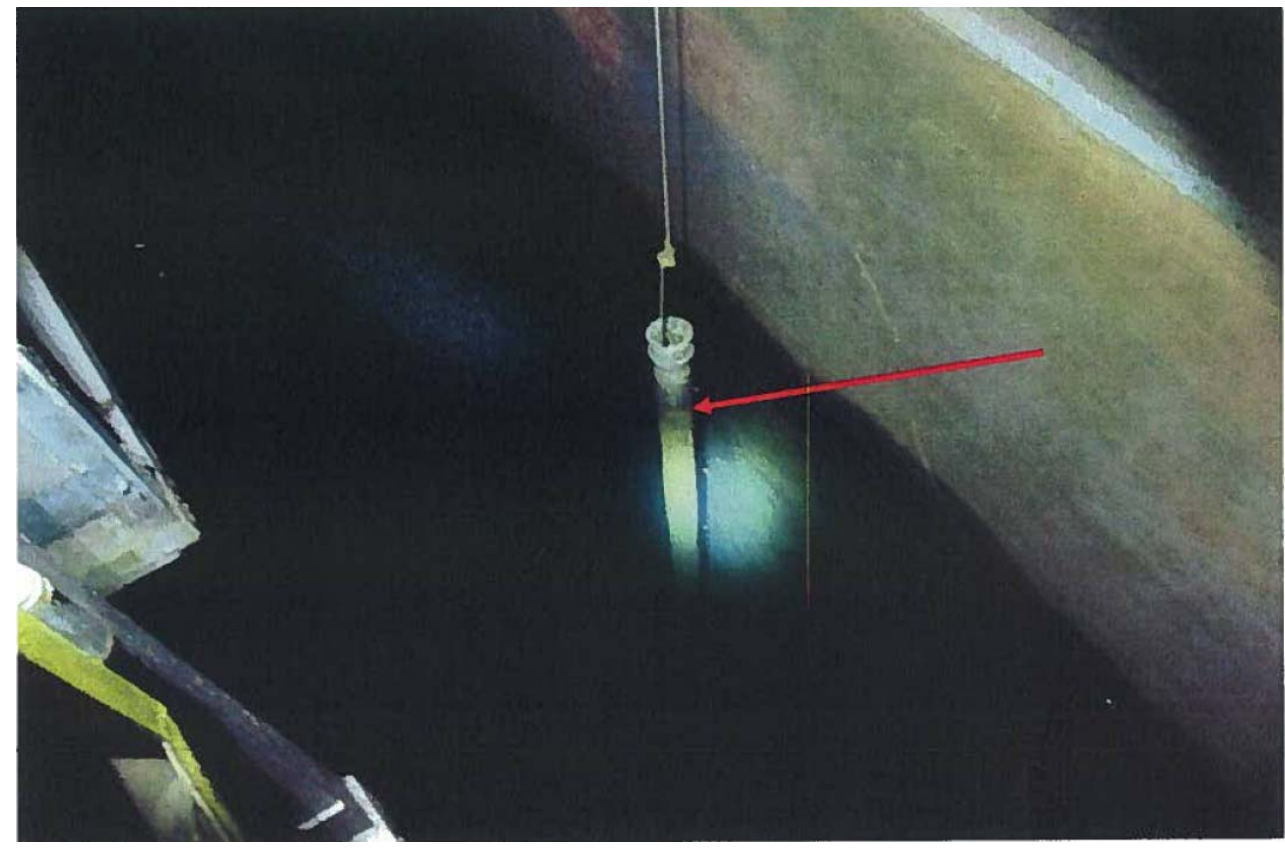

Figure 1. Universal Sleeve Housing (USH) located in the Vertical Tube Storage region of the basin.

\section{Approach}

Pacific Northwest National Laboratory (PNNL) developed a methodology for assessment of hydrogen generation during grouting operations at the K basins at the Hanford Site [3]. Likewise, similar analyses were performed for the $\mathrm{R}$ and $\mathrm{P}$ reactor Disassembly Basins at 
SRS $[4,5]$. These documents were reviewed and applied to the situation for C-basin. The approach is as follows:

1) Aluminum corrodes upon exposure to the high $\mathrm{pH}$ grout.

2) Hydrogen is generated as a consequence of the corrosion reaction.

3) The gas rises to the surface of the water in the form of bubbles.

4) The bubbles will burst at the water surface releasing $\mathrm{H}_{2}$ gas into the stagnant air layer.

This process was modeled by formulating a kinetic law for hydrogen production as a function of the grout temperature and combining it with a model for vertical turbulent diffusion of a light fluid $\left(\mathrm{H}_{2}\right)$ through a heavier miscible fluid medium (air). Vertical turbulent diffusion is a process analogous to molecular diffusion. However, the diffusion coefficient is several orders of magnitude larger than the molecular diffusion coefficient for the $\mathrm{H}_{2}$ /air mixture, because vertical diffusion of the lighter gas is due to buoyancy rather than molecular motion. This model has been confirmed experimentally and has been shown to be effective for predicting diffusion layers that are broader than they are tall (i.e., similar to the basin floor [6]).

The assumptions used in the analysis were:

- The aluminum metal sources are situated on the bottom of the basin pool and are not covered by or contained within structures where hydrogen could accumulate.

- Once the hydrogen reaches the floor of the basin (i.e., 0'-0" elevation), there is sufficient advection to disperse the hydrogen within the building superstructure.

Based on these assumptions the most likely location for hydrogen accumulation is in the region between the water surface and the 0 ' -0 "' elevation.

The first part of the model involved developing a kinetic law for the generation of hydrogen during the corrosion of aluminum. Laboratory tests were performed at PNNL to measure the hydrogen generation rate of non-corroded aluminum metal coupons immersed in both grout and in saturated $\mathrm{Ca}(\mathrm{OH})_{2}$ solution. $\mathrm{Ca}(\mathrm{OH})_{2}$ solution is formed when water is added to the grout. The key results from the tests were:

- The initial hydrogen generation rate of non-corroded aluminum metal in a grout mixture at $25^{\circ} \mathrm{C}$ is $0.3 \mathrm{~cm}^{3} / \mathrm{min}$.

- The initial hydrogen generation rate of non-corroded aluminum metal in $\mathrm{Ca}(\mathrm{OH})_{2}$ solution at $25^{\circ} \mathrm{C}$ is $1.1 \mathrm{~cm}^{3} / \mathrm{min}$.

- The initial hydrogen generation rate of non-corroded aluminum metal in $\mathrm{Ca}(\mathrm{OH})_{2}$ solution at $50^{\circ} \mathrm{C}$ is $5.4 \mathrm{~cm}^{3} / \mathrm{min}$.

- The hydrogen generation rate of non-corroded aluminum metal in grout decreases to approximately $0.15 \mathrm{~cm}^{3} / \mathrm{min}$ after 2 to 3 hours of exposure to the grout mixture at $25^{\circ} \mathrm{C}$. Likewise, the hydrogen generation rate of non-corroded aluminum metal in $\mathrm{Ca}(\mathrm{OH})_{2}$ decreases to approximately $0.27 \mathrm{~cm}^{3} / \mathrm{min}$ at $25^{\circ} \mathrm{C}$ and approximately $0.18 \mathrm{~cm}^{3} / \mathrm{min}$ at $50^{\circ} \mathrm{C}$. The decrease in corrosion rate is due to the 
formation of a corrosion product (principally tricalcium aluminum hydroxide and hydrocalumite) layer on the surface of the aluminum metal.

The Arrhenius equation for the hydrogen generation rate was derived previously for grout and $\mathrm{Ca}(\mathrm{OH})_{2}$ [4]. For grout, the volumetric hydrogen generation rate per unit area of aluminum ( $\left.Q^{\prime}\right)$ is:

$Q^{\prime}=55.68 \exp (-5339 / T)$

where $\mathrm{T}$ is the temperature in ${ }^{\circ} \mathrm{K}$. Similarly, for $\mathrm{Ca}(\mathrm{OH})_{2} \mathrm{Q}$ ' is:

$Q^{\prime}=262.1 \exp (-5339 / \mathrm{T})$

The following conservatisms and uncertainties were considered when applying the data to the $\mathrm{C}$-basin situation.

- The experimentally measured hydrogen generation rate was determined on clean or non-corroded aluminum metal. The surface of the aluminum metal in the basins is corroded. The aluminum metal in the basins has been there for many years and the surface is protected by either a natural thin hydroxide film or a corrosion product layer. In either case, the rate of hydrogen generation from corrosion would be lower than that measured for the non-corroded aluminum metal coupons in the laboratory tests.

- The hydrogen generation rate due to aluminum metal corroding in grout is based on only one relevant gas generation test. However, four tests were conducted in a $\mathrm{Ca}(\mathrm{OH})_{2}$ solution and the results were consistent based on chemical engineering fundamentals (i.e., mass transfer conditions in the grout are poorer than those in the $\mathrm{Ca}(\mathrm{OH})_{2}$ solution). Additionally, the hydrogen gas generation rate for the aluminum in grout was also comparable to other values in the literature. Matsuo et al. measured a rate of $0.105 \mathrm{~cm}^{3} / \mathrm{min}$ for aluminum exposed to Portland cement at room temperature $[7,8]$.

- The hydrogen generation rate for aluminum metal in grout was performed at 27 ${ }^{\circ} \mathrm{C}$. Extrapolation of this result to hydrogen generation rates for higher grout temperatures was made using the test results from aluminum exposed to $\mathrm{Ca}(\mathrm{OH})_{2}$ solution. However, the five-fold increase in hydrogen generation rate with a 30 ${ }^{\circ} \mathrm{C}$ increase in the $\mathrm{Ca}(\mathrm{OH})_{2}$ solution temperature is consistent with literature values for hydrogen generation in grout. Matsuo et al. observed a 3 fold increase in hydrogen generation rate with a $30^{\circ} \mathrm{C}$ increase in an inhibited grout mixture [9].

While the last two bullets do indicate that there is uncertainty in the experimental data due to the limited number of laboratory tests, it is unlikely that this is significant relative to other conservatisms in the analysis.

The mass transport equation was also derived previously [4]. The superficial velocity, $\mathrm{u}_{0}$, was expressed as: 
$\mathrm{u}_{0}=\beta^{2}\left[\mathrm{gH}\left(1-\left(\mathrm{M}_{\mathrm{L}} / \mathrm{M}_{\mathrm{H}}\right) \mathrm{X}_{\mathrm{LFL}}{ }^{3}\right]^{1 / 2}\right.$

where $\beta$ is a proportionality constant equal to 1.64 , $g$ is the gravitational acceleration, $H$ is the distance from the water-air interface to the basin's 0 '- 0 " elevation, $M_{L}$ is the molecular weight of hydrogen, $\mathrm{M}_{\mathrm{H}}$ is the molecular weight of air, and $\mathrm{X}_{\mathrm{LFL}}$ is the volume fraction of hydrogen at the lower flammability limit (LFL).

The following conservatisms and uncertainties were considered when applying the diffusion model to C-basin.

1) The analysis does not account for dissipation of hydrogen between the surface of the water and the 0 ' -0 " elevation of the basin due to advection. Accounting for this phenomenon would minimize the accumulation of hydrogen in this region.

2) The analysis assumed that the hydrogen bubble plume does not expand laterally from the aluminum metal source. In reality, local concentrated sources of aluminum metal will produce a bubble plume which expands laterally as it rises through the water. Thus, the potential for a local deflagration/explosion is overestimated in this analysis.

The incipient flammability condition occurs when the gas generation rate due to corrosion equals the flux of hydrogen through air. The critical condition occurs at the water-air interface when the hydrogen gas concentration exceeds the LFL. The LFL for hydrogen in air is $4 \%$ by volume. To assess safety margins, the calculations were also performed with a criterion of $60 \%$ of the LFL. This value is utilized for safety class operations that involved the handling of radioactive storage vessels [10].

The critical areal density ratio can be derived by equating the kinetic law for hydrogen generation rate to the vertical turbulent diffusion rate of hydrogen when the hydrogen concentration at the surface of the water is the LFL. This derivation was also performed previously [4]. The critical areal density ratio is defined as:

$$
\left(\mathrm{A}_{\mathrm{A}} / \mathrm{A}_{\text {floor }}\right) \mathrm{c}=\mathrm{u}_{0} / \mathrm{Q}^{\prime}
$$

where $A_{A l}$ is the surface area of the aluminum, $A_{\text {floor }}$ is the cross-sectional surface area hydrogen will diffuse through, $\mathfrak{u}_{0}$ is the superficial velocity of the hydrogen gas as it diffuses toward the 0'-0" elevation of the basin, and Q' is generation rate of hydrogen due to corrosion of aluminum. The actual areal density ratio will be compared to the calculated critical ratio. If the actual ratio is greater than the critical calculated ratio, there is risk that the concentration of hydrogen gas at the surface of the water in the basin is greater than the lower flammability limit (LFL). Further precautions would be necessary if this condition exists. Two cases were considered, 1) aluminum exposed to grout only and 2) aluminum exposed to $\mathrm{Ca}(\mathrm{OH})_{2}$ solution. The latter case is considered in grouting operations where there are interruptions for operational or other reasons. In this situation the water is assumed to become saturated with $\mathrm{Ca}(\mathrm{OH})_{2}$. 
Figure 2 shows a plot of the critical areal density ratio as a function of temperature for aluminum exposed to grout. The ratio decreases with temperature as expected due to the increase in corrosion rate, and hence hydrogen generation rate, with temperature. The plot also shows the critical areal density ratio for both $100 \%$ and $60 \% \mathrm{LFL}$.

Figure 3 shows a similar plot for aluminum exposed to $\mathrm{Ca}(\mathrm{OH})_{2}$. The critical areal density ratios are lower than those for the grout, which reflects the higher aluminum corrosion rate. Again the plot also shows the critical areal density ratio for both $100 \%$ and $60 \% \mathrm{LFL}$.

Heat is added to the system during the grout curing process through the heat of hydration. The heat of hydration is the heat evolved due to chemical reactions with water and is dependent upon the constituents present in the cement mix. Experimental data from the literature suggests that the maximum temperature does not occur until 10-20 hours after the curing process begins (See Figure 4 [9]). During the first 3 hours, when hydrogen generation is at a maximum, the temperature is expected to be less than $50^{\circ} \mathrm{C}$ [9]. Since the corrosion reaction decreases significantly after 3 hours due to the formation of corrosion products on the aluminum surface, it is the first 3 hours that are the most critical from the standpoint of hydrogen evolution. Thus, for this evaluation it will be assumed that the maximum temperature of the grout is $50^{\circ} \mathrm{C}$.

One concern is that the grout placement will be interrupted for operational or other reasons. If this is the case, the temperature of the water above the concrete will begin to increase due to the heat of hydration. An energy balance was performed to estimate the maximum temperature rise of the $\mathrm{Ca}(\mathrm{OH})_{2}$ solution. The conservatisms built into the analysis include:

- The energy balance assumed that the grout and basin water were a closed system and there was no thermal losses to the basin structure or to the air above the basin. Only heat conduction from the grout to the basin water was assumed, completely ignoring heat loss via natural convection.

- The quantity of heat generated by the heat of hydration used for the PNNL thermal analysis was for a cumulative 7 day period. This input is extremely conservative given that the critical time period of interest is the first 3 hours after exposure to $\mathrm{Ca}(\mathrm{OH})_{2}$. For the $\mathrm{C}$-basin the heat released during the first day was assumed to be $25 \%$ of the heat released during the 7 days. This assumption takes into account that the heat generation rate is high initially; however, heat generation is not significant to the hydrogen generation rate after the first 3 hours. Therefore, it is less than the cumulative heat generated that is assumed in the PNNL analysis.

The calculations are shown in Appendix 1. The calculation was performed for various grout pour heights, in order to simulate different interruption scenarios. The temperature rise also depends on the depth of the water. The depth of the water in the Horizontal Tube Storage (HTS) area was approximately 10 feet, while in the remaining areas the depth is approximately 23 feet. Therefore, for HTS, the maximum calculated 
temperature was $62^{\circ} \mathrm{C}$, while for the other areas the maximum temperature was $40^{\circ} \mathrm{C}$. This evaluation is conservative as it assumes that operations were interrupted near the conclusion of the initial five foot lift.

\section{Determination of Cross-Sectional Area of the Basin and Actual Aluminum Surface Area}

The assessment was performed to ensure that hydrogen does not accumulate within a local region of the disassembly basin. As mentioned previously, the disassembly basin is divided into five primary regions. Drawings of these areas were studied to determine the cross-sectional area that the hydrogen will diffuse through during the grouting operation [11]. The localized area where most of the aluminum components were located was determined in consultation with D\&D Engineering (see Appendix 2). The calculations are shown in the Appendix 1, and are summarized in Table 1.

Table 1. Cross-Sectional Area of the Disassembly Basin Regions and Aluminum Component Surface Area

\begin{tabular}{|l|c|c|}
\hline \multicolumn{1}{|c|}{ Region of the Basin } & Cross-Sectional Area $\left(\mathbf{f t}^{2}\right)$ & Aluminum Surface Area $\left(\mathbf{f t}^{2} \mathbf{)}\right.$ \\
\hline D\&E Canal & 256 & 51 \\
\hline Horizontal Tube Storage & 2180 & 9202 \\
\hline Vertical Tube Storage & 664 & 1847 \\
\hline Machine Basin & 1989 & 77 \\
\hline Dry Cave & 735 & 394 \\
\hline
\end{tabular}

D\&D Engineering personnel performed a field walk-down to determine the configuration of the aluminum components [1]. Aluminum components that were identified include: universal sleeve housing (USH), safety rod thimble, target bundle, harp, and aluminum scrap. D\&D Engineering performed calculations to estimate the total surface area of aluminum in each region of the basin [12]. These values are summarized in Table 2. The assessment was performed under the assumption that the aluminum components were uniformly distributed in a local region of the basin floor.

\section{Determination of Minimum Ventilation Rate}

If the building was not properly ventilated, conceivably hydrogen could accumulate in the building vapor space at concentrations greater than the LFL. To evaluate this risk, the building was modeled as continuous stirred tank reactor (CSTR). The derivation of the model equations are shown in Appendix 1. The model predicts the accumulation of hydrogen as a function of time and assumed ventilation rate.

Two bounding cases were evaluated. The first case assumes that the aluminum is exposed to grout at a temperature of $50^{\circ} \mathrm{C}$, while the second case assumes that the 
aluminum is exposed to $\mathrm{Ca}(\mathrm{OH})_{2}$ at $62{ }^{\circ} \mathrm{C}$. Two criteria were used to assess the ventilation rates.

1) The ventilation rate needed to keep the hydrogen concentration less than $60 \%$ LFL and LFL for the first day was determined. Given that the corrosion rate decreases significantly after the first day, most of the hydrogen will accumulate during this time.

2) The time necessary for the hydrogen concentration to exceed $60 \%$ LFL and LFL was calculated. For this analysis the gas generation rate will be assumed to be constant and equal to the time averaged, one day hydrogen generation rate. This assumption is conservative for two reasons. First, the generation rate is known to decrease significantly due to passivation of the corrosion reaction. Secondly, the analysis will assume an infinite supply of aluminum in the basin, which clearly is not the case. Nevertheless, this criterion should show the benefits of providing ventilation during the operations.

\section{Results}

Figure 5 summarizes the flammability assessment for each of the basin regions for the condition where the aluminum is exposed to grout. The grout was assumed to be at the maximum temperature of $50^{\circ} \mathrm{C}$. The highest actual areal density ratios were observed for the Horizontal Tube Storage, 4.22, and the Vertical Tube Storage, 2.78. The critical areal density ratio for the $60 \%$ and $100 \%$ criteria is 116 and 249 , respectively. The margins of safety for Horizontal Tube Storage and Vertical Tube Storage are a factor of 27 and 42 , for the $60 \%$ and $100 \%$ criteria, respectively. This margin of safety was considered adequate (i.e., one to two orders of magnitude) when considering the usage of calcium aluminate sulfate grout for the P-reactor grouting operations [13]. At the $100 \%$ criterion these margins of safety increase to 59 for the Horizontal Tube Storage region and 89 for the Vertical Tube Storage region.

For perspective, in order to achieve the critical areal density ratio for the $60 \%$ criterion, the Horizontal Tube Storage region would need to contain approximately 3800 USH's. This value more than doubles to 8150 USH's if the $100 \%$ criterion is utilized. For the Vertical Tube Storage area, the critical areal density ratio for the $60 \%$ criterion could be achieved if there are more than 1160 USH's present; 2470 USH's would need to be present for the $100 \%$ criterion to be exceeded. Therefore, if the D\&D Engineering is confident in the results of the field observations $[1,12]$, the development of a flammable situation in the basin is unlikely.

Figure 6 summarizes the flammability assessment for each of the basin regions, except Horizontal Tube Storage, for the condition where the aluminum is exposed to $\mathrm{Ca}(\mathrm{OH})_{2}$. The $\mathrm{Ca}(\mathrm{OH})_{2}$ was assumed to be at a temperature of $40{ }^{\circ} \mathrm{C}$. The critical areal density for the $60 \%$ and $100 \%$ criteria for these regions is 42 and 90 , respectively. The margins of safety for the Vertical Tube Storage is a factor of 15 for the $60 \%$ criterion. Although this margin is less than for the grouted condition, this margin of safety is also adequate [13]. At the $100 \%$ criterion, the safety factor for this region is 32 . 
In order to achieve the critical areal density ratio for the $60 \%$ criterion, the Vertical Tube Storage region would need to contain approximately $420 \mathrm{USH}$ 's; for the $100 \%$ criterion nearly 900 USH's would need to be present. This result indicates that there is less margin for safety if the operations were to be suspended before the five foot lift was completed. However, if D\&D Engineering is confident in the results of the field observations $[1,12]$, the development of a flammable situation in the basin is unlikely.

Due to the shallower depth of the Horizontal Tube Storage region (i.e., $17 \mathrm{ft}$ ), there is less water available to heat. Therefore, the maximum temperature for the $\mathrm{Ca}(\mathrm{OH})_{2}$ during a five foot lift was calculated to be $62{ }^{\circ} \mathrm{C}$. The critical areal density for the $60 \%$ and $100 \%$ criteria for these regions is 14 and 29 , respectively. The margins of safety for the Horizontal Tube Storage are a factor of 3.3 for the $60 \%$ criterion and 6.9 for the $100 \%$ criterion. These safety factors are less than an order of magnitude, however, would be equivalent to limiting maximum allowable hydrogen concentration to less than $15 \%$ of the LFL. A review of the safety requirements for the Tank Farm Facility indicates that this application would be analogous to a very slow generating tank [14]; that is, a tank where the hydrogen concentration will not achieve the lower flammability limit at steady state. Special controls are required in very slow generating tanks only if the steady state value exceeds $60 \%$ LFL. Thus, the calculations indicate that there is a sufficient margin of safety.

In order to achieve the critical areal density ratio for the $60 \%$ criterion, the Horizontal Tube Storage region would need to contain approximately $460 \mathrm{USH}$ 's; for the $100 \%$ criterion nearly 800 USH's would need to be present. This result indicates that there is less margin for safety if the operations were to be suspended before the five foot lift was completed. However, if D\&D Engineering is confident in the results of the field observations $[1,12]$, the development of a flammable situation in the basin is unlikely.

Figures 7 and 8 summarize the results for the assessment of the effect of ventilation on the accumulation of hydrogen within the building above the basin area. For the case where the aluminum is exposed to grout at $50^{\circ} \mathrm{C}$, the accumulation of hydrogen for three ventilation rates is shown in Figure 7. After Day 1 there is little effect of ventilation rate on the hydrogen accumulation. In all three cases, the concentration of hydrogen was on the order of $0.04 \mathrm{vol} . \%$, which is two orders of magnitude less than the LFL and a factor of 60 less than the $60 \%$ LFL criterion. These concentrations were observed even when the ventilation rate was on the order of $0.1 \mathrm{cubic}$ foot $/ \mathrm{min}$.

The benefit of ventilation can be seen if the operations are extended for more than a day. Figure 7 shows that for a ventilation rate of 5 cubic foot $/ \mathrm{min}$, the hydrogen concentration will barely exceed $60 \% \mathrm{LFL}$ and will never achieve the LFL. At $0.1 \mathrm{cubic}$ foot $/ \mathrm{min}$ the hydrogen concentration above the basin was calculated to exceed $60 \%$ LFL after 60 days and LFL after 100 days. As mentioned before, these concentrations are conservative as they do not account for the decrease in hydrogen generation due to passivation of the aluminum. On the other hand the uncertainties in the surface area of aluminum exposed also factor into this assessment as they did for the assessment of local accumulation of hydrogen. However, if D\&D Engineering is confident in the results of the field 
observations [1, 12], the development of a flammable situation in the vapor space above the basin is unlikely.

For the case where the aluminum is exposed to $\mathrm{Ca}(\mathrm{OH})_{2}$ at $62^{\circ} \mathrm{C}$, the accumulation of hydrogen for three ventilation rates is shown in Figure 8. After Day 1, little effect of ventilation rate on the hydrogen accumulation was observed. In all four cases, the concentration of hydrogen was on the order of $0.3 \mathrm{vol} . \%$, which is more than an order of magnitude less than the LFL and a factor of 8 less than the $60 \%$ LFL criterion. These concentrations were observed even when the ventilation rate was on the order of 0.1 cubic foot $/ \mathrm{min}$.

Figure 8 shows that for a ventilation rate of $50 \mathrm{cubic}$ foot/min, the hydrogen concentration was calculated to never exceed $60 \% \mathrm{LFL}$, while at $30 \mathrm{cubic}$ foot $/ \mathrm{min}$ the hydrogen concentration does not achieve the LFL. At $0.1 \mathrm{cubic}$ foot $/ \mathrm{min}$ the hydrogen concentration is calculated to exceed $60 \%$ LFL after 7.5 days and LFL after 12.5 days. As mentioned before, these concentrations are conservative as they do not account for the decrease in hydrogen generation due to passivation of the aluminum. On the other hand the uncertainties in the surface area of aluminum exposed also factor into this assessment as they did for the assessment of local accumulation of hydrogen. However, if D\&D Engineering is confident in the results of the field observations [1,12], the development of a flammable situation in the vapor space above the basin is unlikely.

\section{Conclusions and Recommendations}

The risk of accumulation of a flammable mixture of hydrogen above the surface of the water during the injection of grout into the $\mathrm{C}$-reactor disassembly area is low if the assessment of the aluminum surface area is reliable. Conservative calculations estimate that there is insufficient aluminum present in the basin areas to result in significant hydrogen accumulation in this local region. The minimum safety margin (or factor) on a $60 \%$ LFL criterion for a local region of the basin (i.e., Horizontal Tube Storage) was greater than 3. Calculations also demonstrated that a flammable situation in the vapor space above the basin is unlikely. Although these calculations are conservative, there are some measures that may be taken to further minimize the risk of developing a flammable condition during grouting operations.

1. Minimize the initial temperature of the water and grout as much as practical. Lower temperatures will mean lower hydrogen generation rates.

2. Ventilate the building above the basin rim as much as practical (e.g., leave doors open and operate fans) to further disperse hydrogen.

3. Minimize interruptions to the grout placement process as much as possible. Interruptions will result in higher water temperatures and hence higher hydrogen evolution rates.

4. Grout areas where the actual areal density ratios are the highest (e.g., Horizontal Tube Storage and Vertical Tube Storage) first. Thus, the areas that will produce the highest volume of hydrogen will have the maximum building volume in which to expand. 


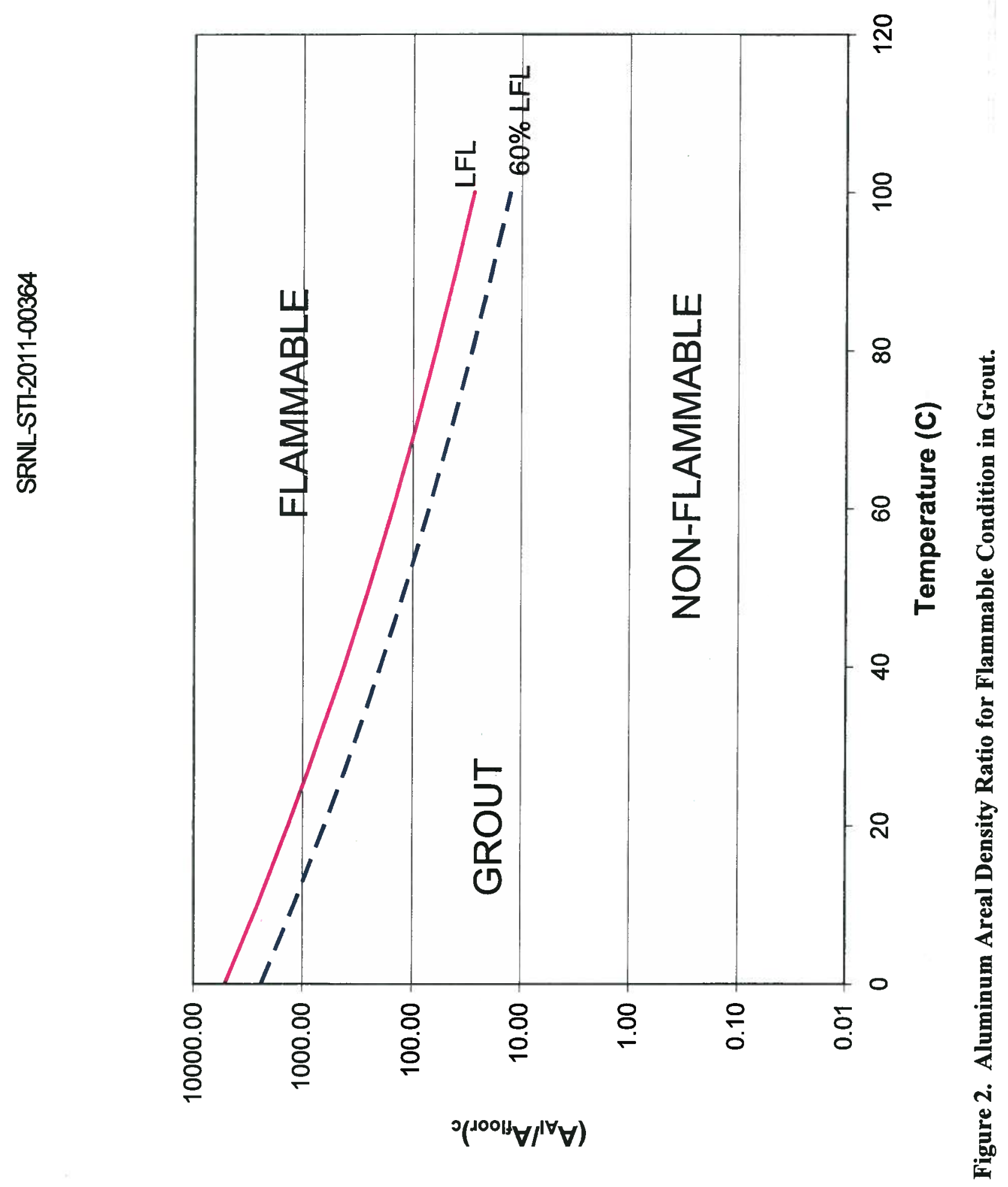




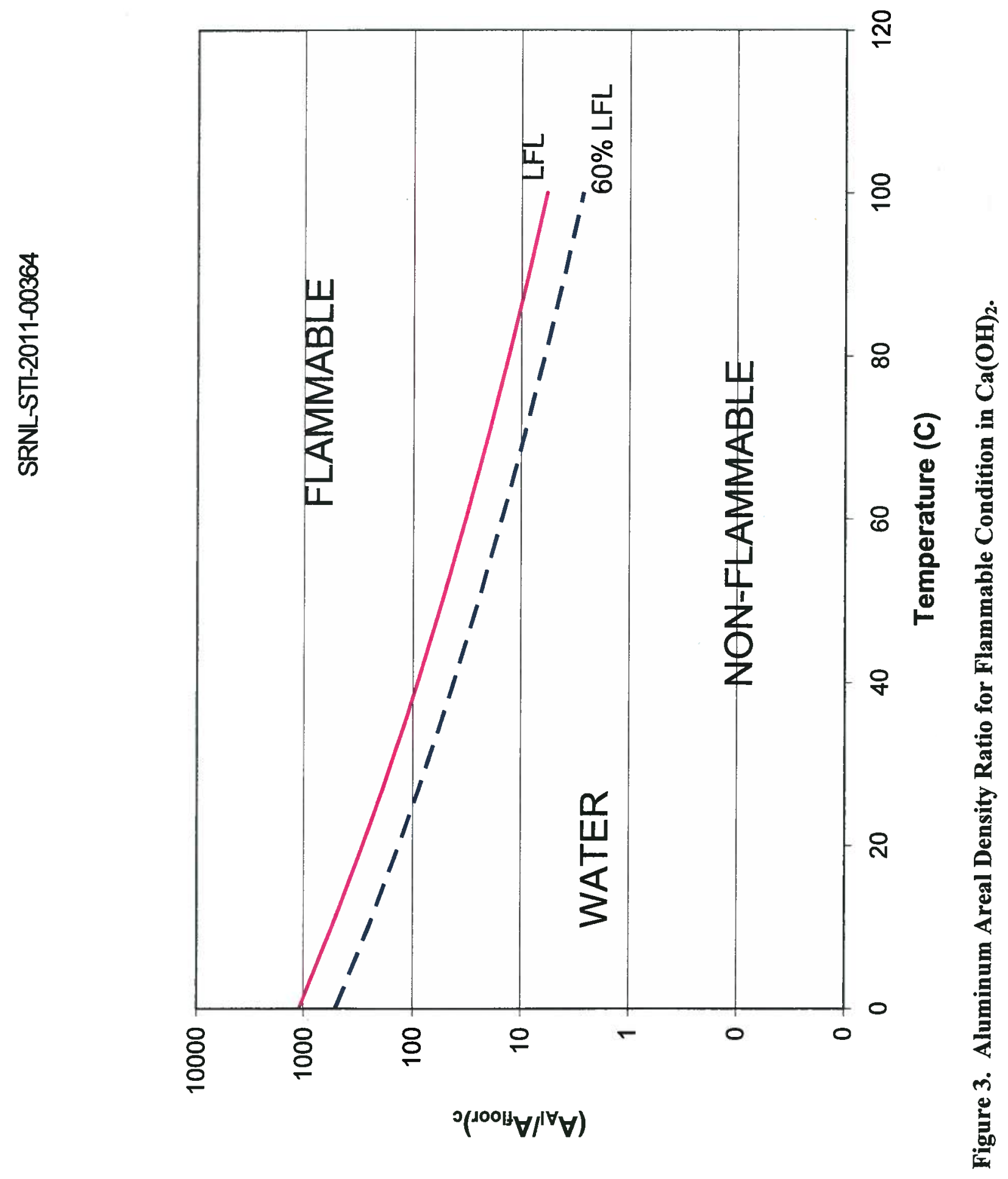


兽
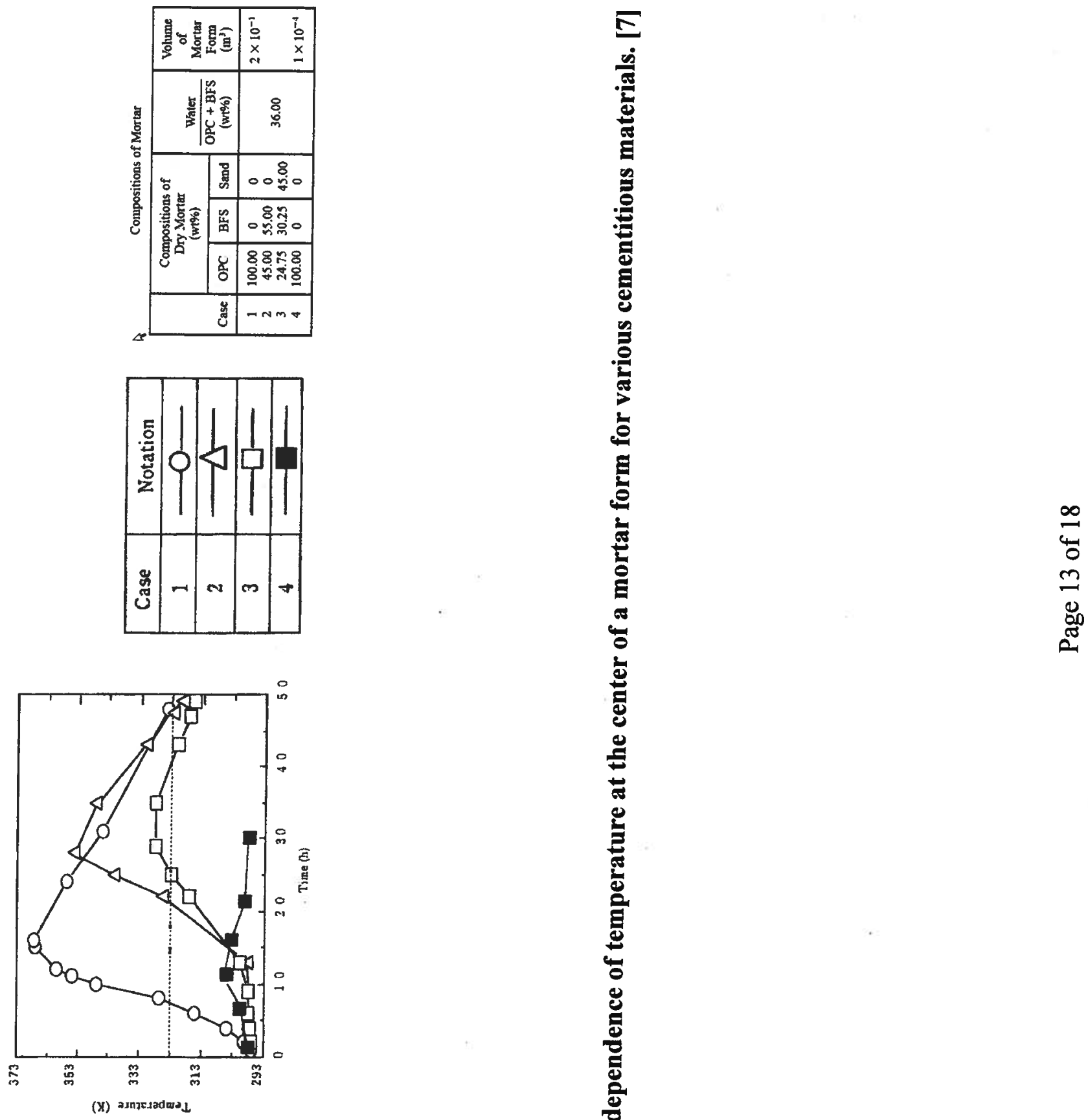


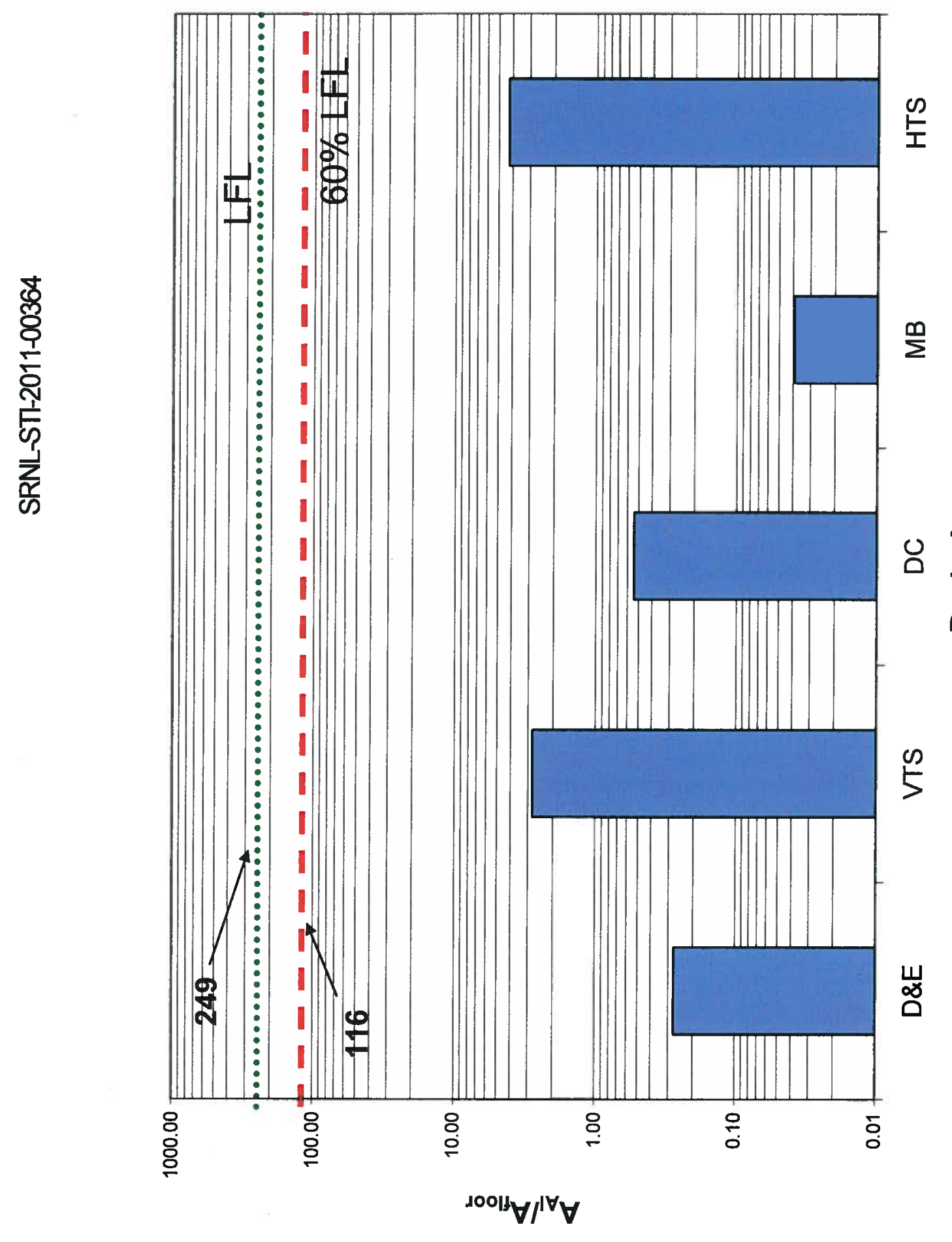

$\infty$
$\square$
0
\pm
0
0
0
0 


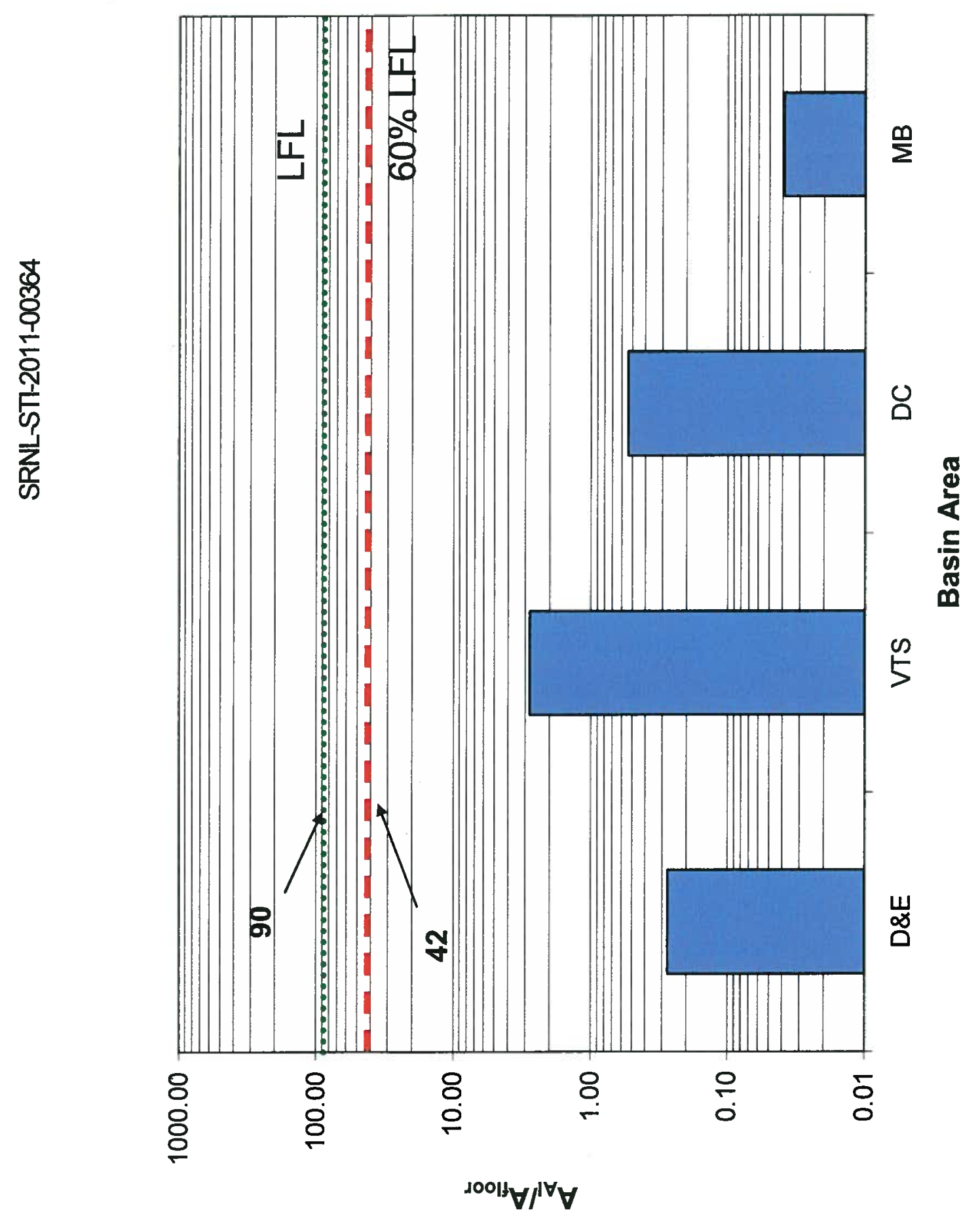

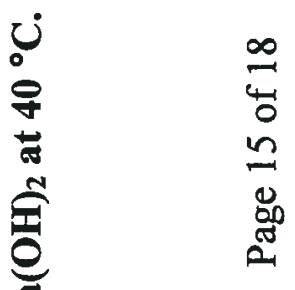




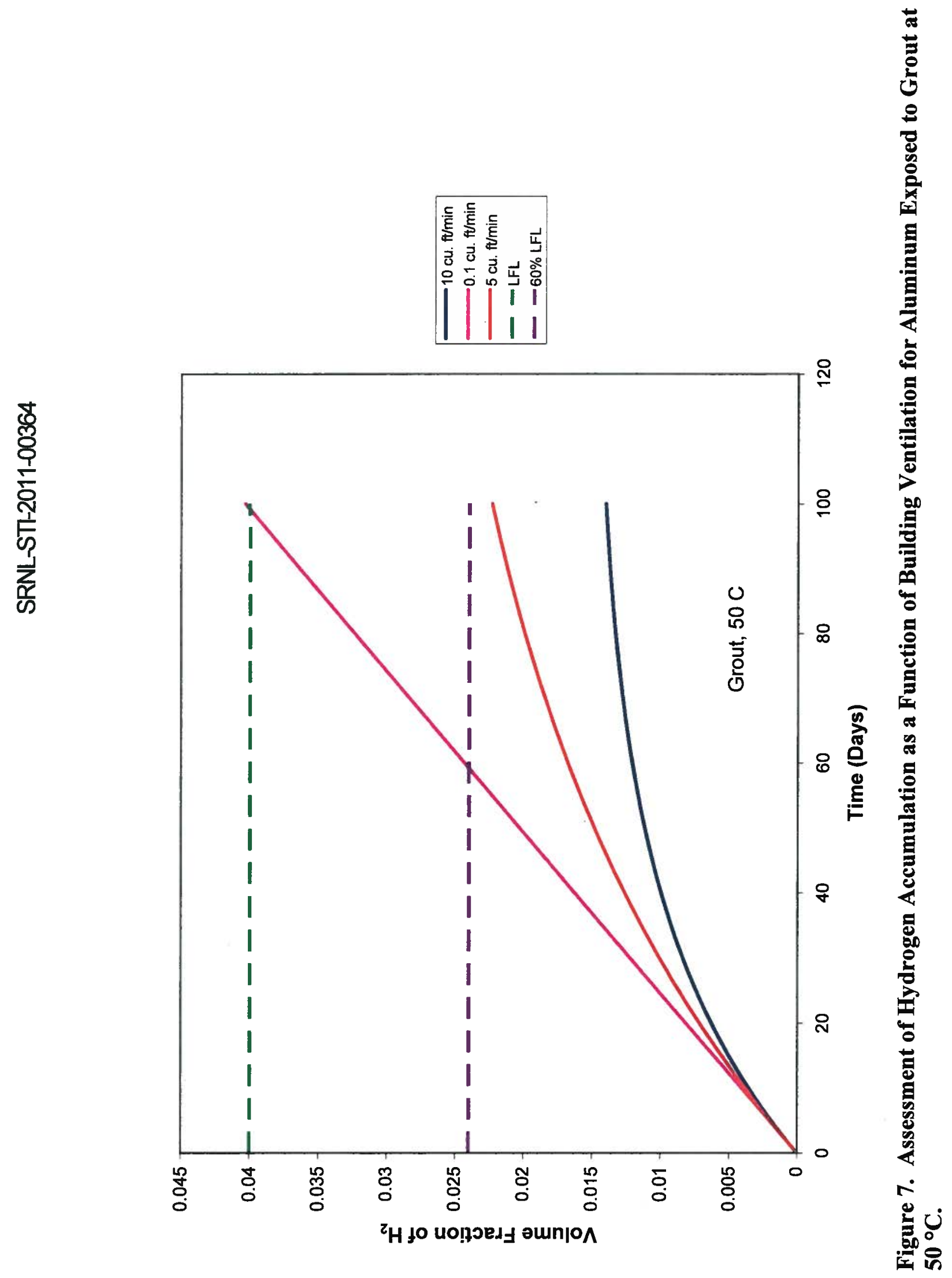




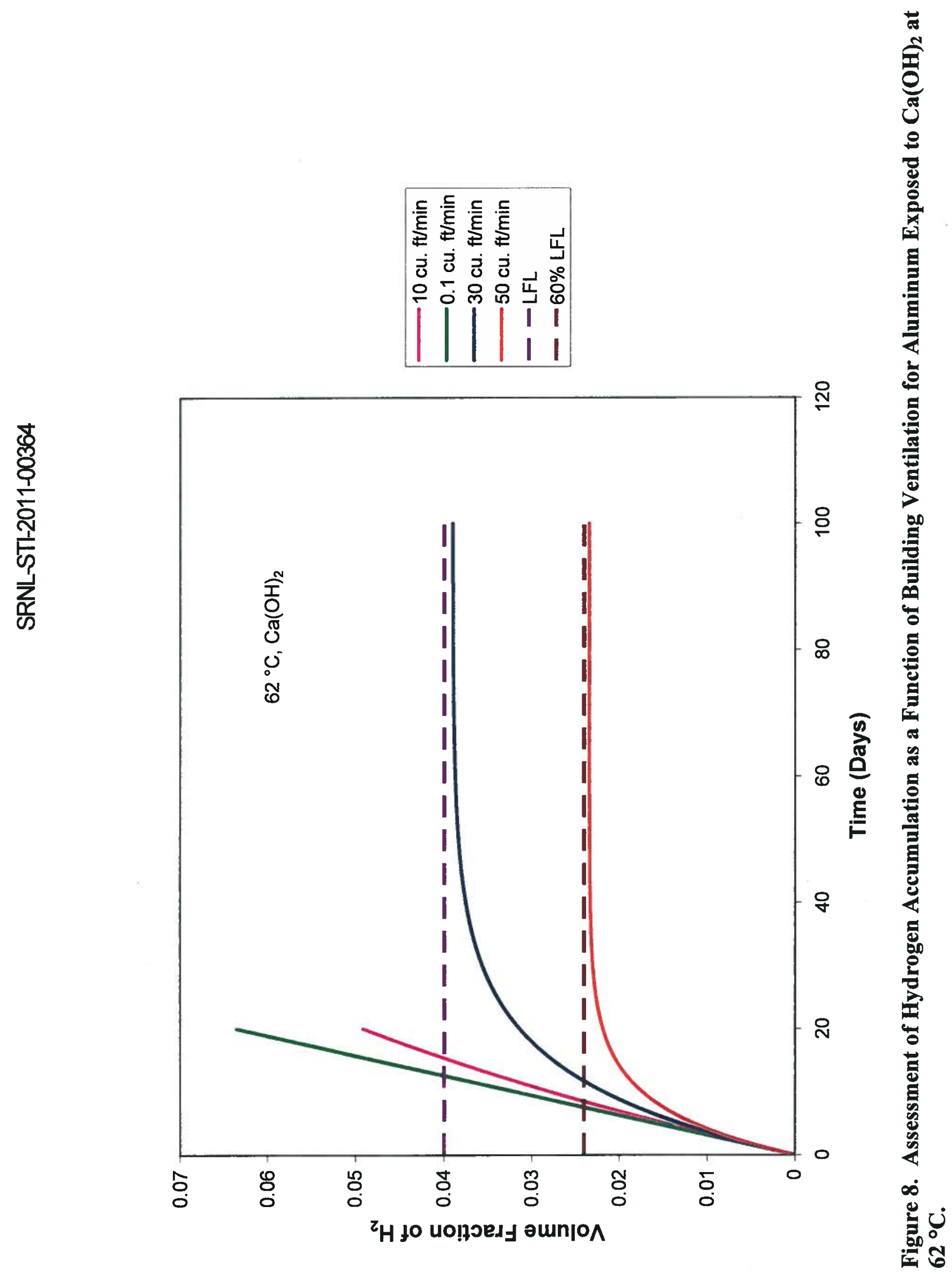




\section{References}

1. W. B. Griffin, et.al., "Building 105-C Disassembly Basin (DB) Engineering Guidance for Scrap Relocation", SDD-2011-00058, Rev. 0, May 17, 2011.

2. S.-M. Moon and S.-I. Pyun, "The corrosion of pure aluminium during cathodic polarization in aqueous solutions", Corrosion Science, Vol. 39, pp. 399-408, 1997.

3. S. M. Short and B. M. Parker, "Potential for Generation of Flammable Mixtures of Hydrogen from Aluminum-Grout Interaction During Basin Grouting", PNNL15156, April 2005.

4. B. J. Wiersma, "Assessment of the Potential for Hydrogen Generation During Grouting Operations in R-reactor Disassembly Basin" SRNL-STI-2009-00278, April, 2009.

5. B. J. Wiersma, "Assessment of the Potential for Hydrogen Generation During Grouting Operations in P-reactor Disassembly Basin" SRNL-STI-2009-00364, June, 2009.

6. M. Epstein and J. P. Burelbach, "Transient Vertical Mixing by Natural Convection in a Wide Layer", Int. J. Heat Mass Transfer, Vol. 43, pp. 321-325.

7. T. Matsuo, T. Nishi, and M. Matsuda, "LiNO ${ }_{3}$ Addition to Prevent Hydrogen Gas Generation from Cement-Solidified Aluminum Wastes", J. Nuclear Science Technology, Vol. 32, No. 9, pp. 912-920, 1995.

8. T. Matsuo, et al., " $\mathrm{LiNO}_{3}$ Effect on Corrosion Prevention of Aluminum with Complex Shapes", J. Nuclear Science and Technology, Vol. 34, No. 8, pp. 823828, 1997.

9. T. Matsuo, et al., "Influence of Increased Temperature from Cement Hydration on Aluminum Corrosion Prevention when $\mathrm{LiNO}_{3}$ is Added to the Cement", Nuclear Technology, Vol. 125, pp. 332-336, March 1999.

10. B. J. Wiersma, "Assessment of the Potential for Hydrogen Generation During Grouting Operations in the R- and P-Reactor Vessels" SRNL-STI-2009-00639, Rev. 2, June, 2010.

11. C-Basin Drawings
W134454
W134417
W134473
W134486

12. W. B. Griffin, "Surface Area of Aluminum Components and Material in 105-C Disassembly Basin", SDD-2011-00072, June 20, 2011.

13. B. J. Wiersma, "Compatibility of Stainless Steel and Aluminum Reactor Components with the Calcium Aluminate Sulfate Mix Design Utilized for Grouting of the P-Reactor Vessel", SRNL-STI-2010-00600, October, 2010.

14. B. C. Landeene, "CSTF Flammability Control Program", WSRC-TR-2003-00087, Rev. 17, December 2010. 
SRNL-STI-2011-00364

\section{APPENDIX 1}

Al-1 
SRNL-STI-2011-00364

C SR 25-10) (Re v6-18.92)

ENGINEERING COMPUTATION SHEET P. A 1 - 2

Title of Project C Reactor Disassembly Basin $\mathrm{H}_{2}$ Project No.

Subject

Computer BJWiersma

Works

Date

$6 / 16 / 11$

Sheet No.

Background

- Aluminum component debris is located near the bottom of the $C$ reactor disassembly basin. There are five lora areas in the basin: Dry caves, Horizontal Tube Storage, Vertical Tube Storage, Machine Basin, and D\&E canal.

- Location and number of components were determined during a field walkdown by DAD Engineering personnel (Ref.1)

- Surface area of immersed aluminum were calculated by D\&D Engineering personnel (Refl).

- The water level in the basin is 79" below floor level. During grouting operations the water will evaporate such that the water level remain constant.

- The depth of the Horizontal Tube Storage area is 17 feet. The depth of all remaining areas is $30 \mathrm{ft}$, with the exception of small isolated areas that have a depth of 50 feet

- Aluminum materials are located on the floor of the basin.

- The grout will be poured in 5 foot lifts. Most of the componets will be covered by the first lift.

1) W.B. Griffin, et.al., "Building $105-c$ Disassembly Basin (DB) Engineering Guidance for Scrap Relocation", SDD-2011-00058, Rev.0, May 17,2011.

2) W.B. Griffin, "Surface Area of Aluminum Components and Material in 105-C Disassembly Basin", SDD-2011-00072, Tune 20,2011. 
SRNL-STI- $2011-00364$

CSR 25-1(t (Rev $(6 \cdot 18-6) 2)$

ENGINEERING COMPUTATION SHEET

P. $A 1-3$

Title of Project C-Reactor Disassembly Basin $\mathrm{H}_{2}$

Project No

Subject

Computer BJWiersma

Works

$6 / 16 / 11$

Sheet No. 2

Background (cont.)

- Corrosion will occur in both the water and grout. The $\mathrm{pH}$ of the water will increase with time due to exposure to the grout. If a lift is suspended, these calculations assume that the aluminum is exposed to $\mathrm{Ca}(\mathrm{OH})_{2}$

- Calculation determines whether or not hydrogen accumulates at the surface of the water during grouting operations.

- 60\%. LFL criterion will be used to determine margin on safety (re ff) Model

Determination of Superficial Velocity (uso) (ref. 3)

See spreadsheet C-basin $H_{2}$ generation. $x / s$, worksheet VTD calls

$$
\begin{aligned}
u_{0} & =\beta^{2}\left[g H\left(1-\left(M_{L} / M_{H}\right) X_{L F L}^{3}\right]^{1 / 2}\right. \\
\beta & =\text { proportionality constant }=0.164 \\
\dot{g} & =\text { gravity }=9.8 \mathrm{~m} / \mathrm{s}^{2}
\end{aligned}
$$

$H=$ distance from water to floor $=79$ inches $=2.0$ meters

$M_{2}=$ Molecular weight of $H_{2}=2 \mathrm{~g} /$ mole

$M_{H}=$ Molecular weight of air $=29 \mathrm{~g} /$ mole

$X_{L F L}=0.04$ for calculations assume $60 \%$ LFL will provide safety margin $\therefore X_{L F L}=0.024$ (reft)

$$
u_{0}=4.27 \times 10^{-4} \mathrm{~m}^{3} / \mathrm{m}^{2}-\mathrm{s}
$$

Reference

3) B.J. Wiersma, "Assessment of the Potential for Hydrogen Generation During Grouting Operations in R-Reactor Disassembly Basin", SRNL-STI-2009-00278, April 2009. 
(SK $25-10(\mathbb{R} 2 w(6-18-92)$

ENGINEERING COMPUTATION SHEET

Tittle of Project C Reactor Disassembly Basin $\mathrm{H}_{2}$ Project No.

Subject

Works

Computer BJW

Date $6 / 16 / 1$

Sheet No.

Determination of Critical Areal Density Ratio

$$
\left(\frac{A_{A 1}}{A_{\text {floor }}}\right)_{C}=\frac{U_{0}}{Q_{H_{2}}^{\prime}}
$$

Determine $A_{A 1} / A_{\text {floor }}$ as a function of temperature see "C-basin $H_{2}$ Generation" spreadsheet, worksheet VTD calces

Areal Density Ratio for Grout

Areal Density Ratio for $\mathrm{Ce}(\mathrm{OH})_{2}$

\begin{tabular}{c|cc|c}
$T\left({ }^{\circ} \mathrm{C}\right)$ & $\left(A_{\left.A 1 / A_{\text {A op }}\right)_{C}}\right.$ & $T\left({ }_{C}{ }_{C}\right)$ & $\left(A_{A 1} / A_{\text {floor }}\right)_{C}$ \\
\hline 0 & 2393 & 0 & 508 \\
10 & 1199 & 10 & 255 \\
20 & 1630 & 20 & 134 \\
30 & 345 & 30 & 73 \\
35 & 259 & 35 & 55 \\
40 & 197 & 40 & 42 \\
50 & 176 & 50 & 25 \\
60 & 71 & 60 & 15 \\
70 & 44 & 70 & 9 \\
80 & 28 & 80 & 6 \\
90 & 19 & 90 & 4 \\
100 & 13 & 100 & 3
\end{tabular}

Note: $X_{L F L}=0.024$ or $60 \% \mathrm{LF}$

Determination of Amount of Aluminum

Summary of Reference 2

$\frac{\text { Area }}{\text { Horizontal Tube Storage }} \frac{A_{A_{11}}\left(\mathrm{H}^{2}\right)}{9328}$

Machine Basin

77

Dry Cave

394

Dry Cave -Center Pen

394

Vertical Tube Storage 580

$D \notin E$ Canal

70 
$\operatorname{cosk} 25-10(\operatorname{Rev}(6-18-1) 2)$

ENGINEERING COMPUTATION SHEET

SRNL-STI- 2011-00364

Title of Project $\mathrm{C}$ - Reactor Disassembly Basin $\mathrm{H}_{2}$

P. $A 1-4$

Subject

Project No.

Computer BJWiersma

Works

Date $6 / 16 / 11$

Sheet No. 3

Corrosion Rate/Hydrogen Generation Rate (see refl)

For Grout

$$
Q_{H_{2}}^{\prime}=55.68 \exp (-5339 / \mathrm{T}) \quad T=\text { Temperature in }^{\circ} \mathrm{K}
$$

For $\mathrm{Ca}(\mathrm{OH})_{2}$

$$
Q_{H_{2}}^{\prime}=262.1 \exp (-5339 / T)
$$

Calculate $Q_{H_{2}}^{\prime}$ as a function of $T$. Shown in spreadsheet "C-basin $\mathrm{H} 2$ generation" on worksheets "Mol Diffusion Calces" and "VTD calls"

$\mathrm{H}_{2}$ Generation for grout

$$
\mathrm{H}_{2} \text { Generation for } \mathrm{Ca}(\mathrm{OH})_{2}
$$

\begin{tabular}{c|c}
$T\left({ }^{\circ}\right)$ & $Q_{H_{2}}^{\prime}\left(\mathrm{m}^{3} / \mathrm{m}^{2} \mathrm{~s}\right) \times 10^{7}$ \\
\hline 273 & 1.79 \\
283 & 3.57 \\
293 & 6.79 \\
303 & 12.4 \\
308 & 16.5 \\
313 & 21.7 \\
323 & 36.9 \\
333 & 60.6 \\
343 & 96.7 \\
353 & 150 \\
363 & 228 \\
373 & 338
\end{tabular}

\begin{tabular}{c|l}
$T\left({ }^{\circ} \mathrm{K}\right)$ & $Q_{\mathrm{H}_{2}}\left(\mathrm{~m}^{3} / \mathrm{m}^{2}-\mathrm{s}\right) \times I$ \\
\hline 273 & 8.42 \\
283 & 16.8 \\
293 & 32.0 \\
303 & 58.4 \\
308 & 77.7 \\
313 & 102 \\
323 & 174 \\
333 & 285 \\
343 & 455 \\
353 & 708 \\
363 & 1070 \\
373 & 1590
\end{tabular}

Reference

4) B.T. Wiersma, "Assessment of the Potential for Hydrogen Generation During Grouting Operations in the R- and P-Reactor Vessels", SRNL-SII-1009-00639, Reva May 2010. 


$$
\text { SRNL-STI-2011-00364 }
$$

COST $25-111$ (Revet. IX .5)

ENGINEERING COMPUTATION SHEET

P. $4 /-5$

Title of Project C Reactor Disassembly Basin $\mathrm{H}_{2}$

Subject
Project No.

Works

Date $6 / 16 / 11$

Sheet No. 4

Computer BJWiersma

Determination of Critical Areal Density Ratio

$$
\left(\frac{A_{11}}{A_{f 100 r}}\right)_{c}=\frac{u_{0}}{Q_{H_{2}}^{\prime}}
$$

Determine $A_{A 1} / A_{f 100}$ as a function of temperature. The values for 60\% LFL and 100\% LFL will be compared for grout and $\mathrm{Ca}(\mathrm{OH})_{2}$. See "C-basin $\mathrm{H}_{2}$ Generation" spreadsheet, Worksheet VTD cakes.

Areal Density Ratio for Grout

Areal Density Ratio for $\mathrm{Ca}\left(\mathrm{OH}_{2}\right.$

$T\left({ }^{\circ} \mathrm{C}\right) \quad\left(A_{A 1} / A_{\text {floor }}\right)$.

$\left(A_{A 1} / A_{\text {dior }}\right)_{C}$

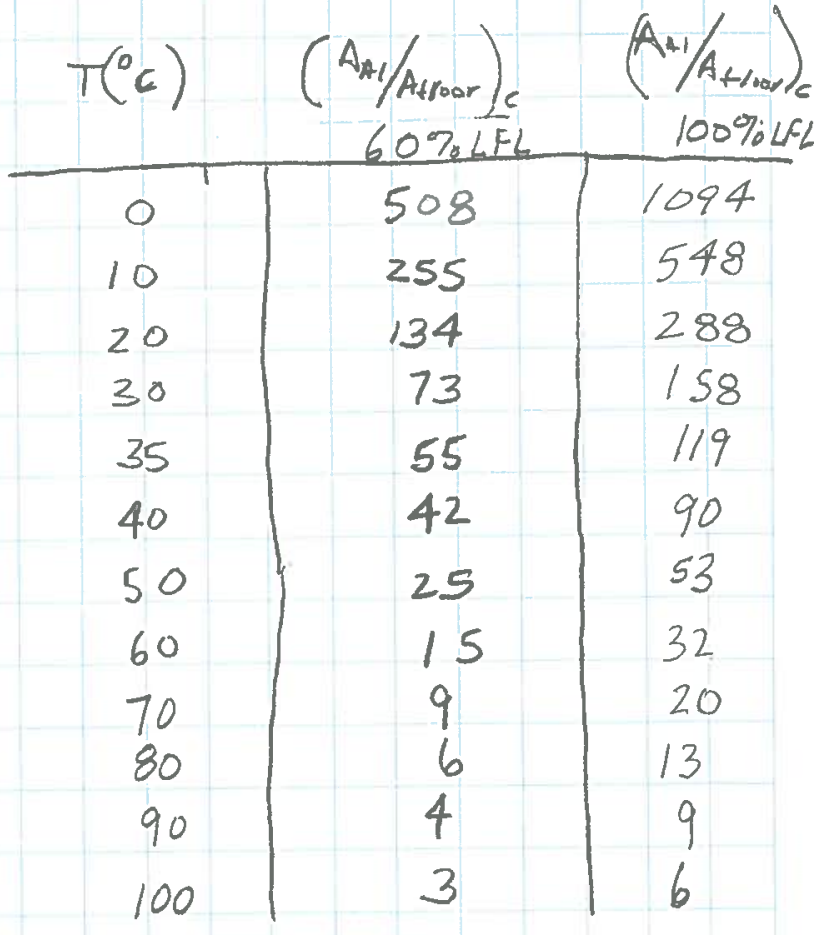

Determination of Amount of Aluminum Summary of Reference 2

Area

Horizontal Tube Storage

Machine Basin

Dry Cave

Vertical Tube Storage

$D \notin E$ Canal
$\frac{A_{A 1}\left(f t^{2}\right)}{9202}$

77

$394^{*}$

1847

70 
Title of Project C-Reactor Disassem bly Basin $\mathrm{H}_{2}$

Project No.

Subject

Cross-Sectional Areas [See Appendix 2 for e-mail from W. B. Griffin]

Vertical Tube Storage (VTS)

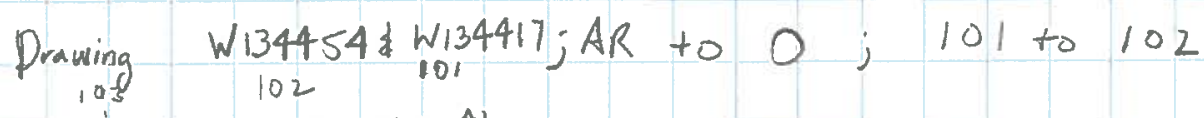

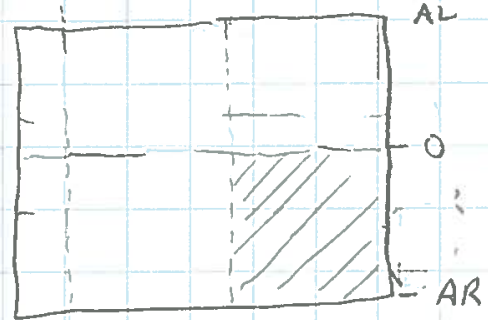

AR to 0 is $32 \mathrm{ft} ; 101$ to 102 is $20.75^{\prime}$

- Control Rods located in this area; Represents $76.2 \%$ of surface area $\left(202,718\right.$ in $^{2}$ out of 266,01859 in) in VTS

- 2 of 3 ush's jocated in area $18,912 \mathrm{sg}$. inches

- Estimated 25 orifice sleeves $(-25 \%$ of that

Area $=32^{\prime} \times 20.75^{\prime}$ in all VTS): $8133 \mathrm{in}^{2}$

$$
=664 \mathrm{ft}^{2}
$$

- Estimated 249,275 in in area; 2940

- Assume all aluminum in this area

Machine Basin (MB)

$\log _{101}$ Drawing $_{106} 5_{105} 1^{\prime}$ south of AR to $0 ; 105$ to 108

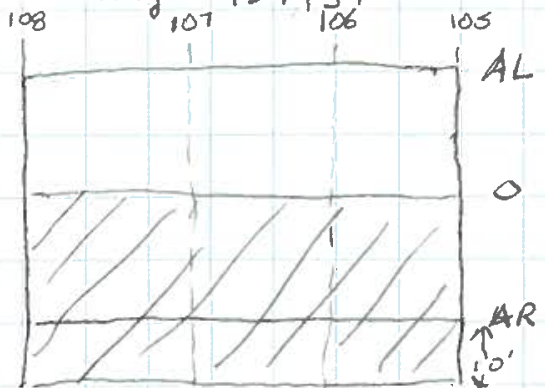

ARto 0 is $32 \mathrm{Ht} ; 105$ to 108 is $62.17 \mathrm{ft}$

- Safety Rod Thimble and Sepfifoil located in this region

$$
\begin{aligned}
\text { Area } & =32 \times 62.17 \\
& =1989 \mathrm{ft}^{2}
\end{aligned}
$$




$$
\begin{aligned}
& \text { SRNL-STI-2011-00364 } \\
& \text { P. A1-7 }
\end{aligned}
$$

()SR 25.10 (R ut 6-18-42)

ENGINEERING COMPUTATION SHEET

Title of Project C -Reactor Disassembly Basin $\mathrm{H}_{2}$ Project No.

Subject

Works

Computer B.J. Wiersma

Date

$6 / 26 / 11$

Sheet No. 6

$\begin{aligned} & \text { Cross -Sectional Areas (cont.) } \\ & \text { Horizontal Tube Storage (UTS) }\end{aligned}$

Drawing W134454\&W/34473 AL to $20^{\circ}$ North of AL; 101 to 107

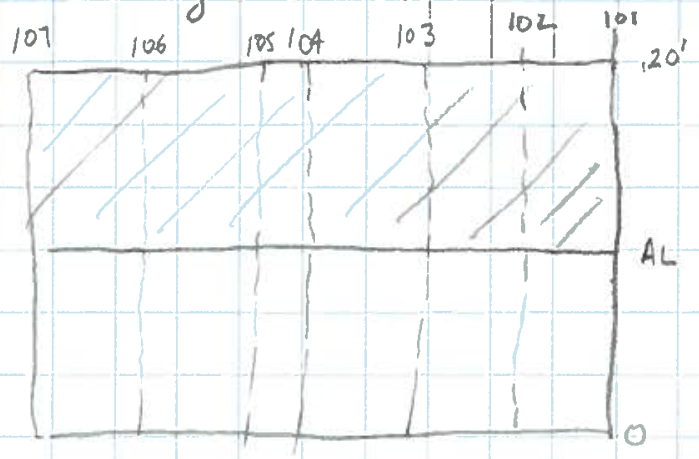

- Slatted Rack in this area;

1,222,144 sq. in represents $92 \%$ of Aluminum in HTS

- Assume all aluminum is in this region of the HTS

$$
\begin{aligned}
\text { Area } & =20^{\prime} \times 109^{\prime} \\
& =2180 \mathrm{ft}^{2}
\end{aligned}
$$

Dry Cave (DC)

Drawing W134454\$W/34486 30 foot (south of AR); 102 to 103 103 102 101

103

- 6. 4SH's located in

$30^{\prime}$ center pen area

$$
\begin{aligned}
\text { Area } & =30^{\prime} \times 24.5^{\prime} \\
& =735 \mathrm{ft}^{2}
\end{aligned}
$$


()SK 25-10) (Rev (o- I R-6)

ENGINEERING COMPUTATION SHEET

SRNL-STI-2011-00364

P. $A 1-8$

Title of Project

C- Reactor Disassembly Basin $\mathrm{H}_{2}$

Project No.

Subject

Works

computer BJWiersma

Date

$6 / 26 / 11$

Sheet No. 7

D LE Canal

$\sqrt{1 S} \quad P\left\{f_{\mathrm{ft}}\right.$
Drawings W/34454,W/344/7)

$64+$ in length

$$
\begin{aligned}
\text { Area } & =64 \mathrm{ft} \times 4 \mathrm{ft} \\
& =256 \mathrm{ft}^{2}
\end{aligned}
$$

Actual Areal Density

Area

D $\$$ Canal

Vertical Tube Storage

Dry Cave

Horizontal Tube Storage

Machine Basin
$\frac{A_{A 1} / A_{11000}}{0.27}$

2.78

o. 54

4.22

0.04

Heat Transfer Calculations

Determine the final temperature of the water and grout after five foot lift has been poured.

Mass of grout and water

Qq Density of grout $125 \mathrm{1b} / \mathrm{ft}^{3}$ reference 3

$\rho_{w}$ Density of water $62.4 \mathrm{lb} / \mathrm{ft}^{3}$

Depends on pour height, $h$

$$
m_{\text {grout }}=A_{\text {floor }} h \times \rho_{g}
$$

water For Horizontal Tube Storage (Note: Depth $=17 \mathrm{ft}-6.5833=10.4167 \mathrm{ft}$ ) For all others Depth $=30 \mathrm{ft}-6.5833=23.4167 \mathrm{ft}$

$$
m_{w}=A_{\text {floor }}(\text { Depth }-h) \times \rho_{w}
$$


USK $25-10(\operatorname{Rev} 6-18-92)$

ENGINEERING COMPUTATION SHEET

SRNL-STI-2011-00364

P. Al- 9

Title of Project C -Reactor Disassembly Basin $\mathrm{H}_{2}$

Project No.

Subject

Works

Computer BJWiersma

Date

$6 / 18 / 11$

Sheet No. 8

$C_{p}-$ Specific Heat See reference 3

$$
\begin{aligned}
& C_{p, g}=0.25 \mathrm{BTU}(16-F) \\
& C_{p, w}=1.0 \mathrm{BTu} /\left(16-{ }^{\circ} F\right)
\end{aligned}
$$

Temperature

Grout Temperature $=T_{g}=$ Assume constant@ maximum value of $50^{\circ} \mathrm{C}\left(120^{\circ} \mathrm{F}\right)$

Water Temperature $=T_{w}=$ Initial ambient temperature of $27^{\circ} \mathrm{C}\left(80^{\circ} \mathrm{F}\right)$

Analysis Methodology

1. Law of Thermodynamic Energy Balance

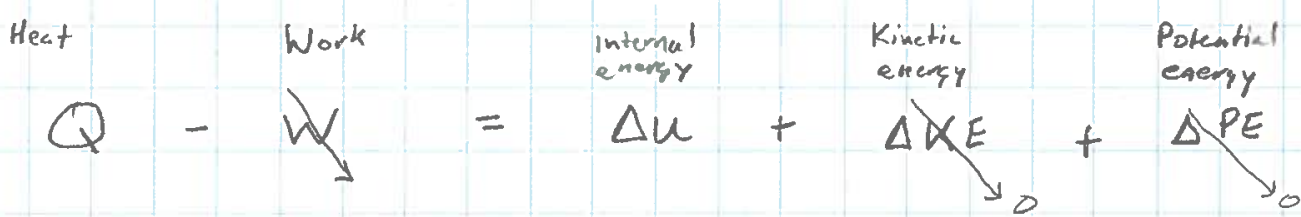

$$
\begin{aligned}
& Q=\Delta u \\
& \Delta u=m c_{p}\left(T_{f}-T_{i}\right)
\end{aligned}
$$

$Q$

Assumed same heat transfer as reference 3

$$
\begin{aligned}
& Q=\bar{Q} \times \rho_{g} \times A_{\text {floor }} \times h \\
& \bar{Q}=40 \text { BTU/1bm } \\
& Q=\Delta u_{g}+\Delta u_{w}^{\text {rout }}
\end{aligned}
$$


( SSR 25-10( RLV 6-18-42)

SRNL-STI-2011-00364

Title of Project $\mathrm{C}$-Reactor Disassembly Basin $\mathrm{H}_{2}$

P. $A 1-10$

Subject

Computer $\quad B J W$

Works

Date $6 / 18 / 11$

Sheet No. 9

$$
T_{f}=\frac{\left[Q+m_{g} c_{p, g} T_{i, g}+m_{w} c_{p, w} T_{i, w}\right]}{\left[m_{g} c_{p, g}+m_{w} c_{p, w}\right]}
$$

Calculations were performed on spreadsheet "C-bosin Temperature" worksheet "Sheet 1"

Results

\begin{tabular}{c|c|c} 
& Horizontal Tube Storage & All other Areas \\
Pour height, hetH) & Temperature $\left({ }^{\circ} \mathrm{C}\right)$ & Temperature ${ }^{\circ} \mathrm{C}$ \\
\hline 0.5 & 29 & 28 \\
1.0 & 32 & 29 \\
1.5 & 35 & 30 \\
2.0 & 38 & 32 \\
2.5 & 42 & 33 \\
3.0 & 45 & 34 \\
3.5 & 49 & 36 \\
4.0 & 53 & 37 \\
4.5 & 57 & 38 \\
5.0 & 62 & 40
\end{tabular}

Maximum Temperatures

Grout $-50^{\circ} \mathrm{C}$

Water - Horizontal Tube Storage: $62^{\circ} \mathrm{C}$

All other Areas: $40^{\circ} \mathrm{C}$ 
SRNL-STI- 2011-00364

()SR $2 S-10\langle\operatorname{ReN}(6-18.92)$

ENGINEERING COMPUTATION SHEET

p. Al- 11

Title of Project $C$ - Reactor Disassembly Basin $H_{2}$ Project No

Subject

Works

Computer B.J. Wiersma Date $7 / 6 / 11$

Sheet No. 10

Model for Determining Minimum Building Ventilation

- Building can be modeled as a continuous stirred tank reactor to assess the accumulation of $H_{2}$ in the vapor space above the basin

$$
C_{A} V_{0}-C_{A_{\text {out }}} V_{0}+R_{A}=\frac{d\left(C_{A} V_{b}\right)}{d t}
$$

$C_{A}=$ Concentration of $H_{2}$ flowing into building $=0$

$C_{\text {tact }}=$ Concentration of $\mathrm{H}_{2}$ flowing out building

$R_{A}=$ Hydrogen generation rate due to alumina m corrosion $V_{0}=$ ventilation rete

$V_{b}=$ Volume of vapor space above the basin

$$
-C_{A_{\text {out }}} V_{0}+R_{A} \cdot=V_{b} \frac{d C_{\text {Ant }}}{d t}
$$

Rewrite equation in terms of volumetric generation rate and volume fraction of $\mathrm{H}_{2}$. Use ideal gas law.

$$
\begin{aligned}
& C_{\text {out }}=C x_{\text {out }} \text { where } x_{\text {Host }}=\text { volume fraction of } H_{2} \\
& R_{A}=\frac{d \eta_{A}}{d t}=\frac{D}{R T} \frac{d V_{A}}{d t} \quad \frac{d V_{A}}{d t}=\text { Volumetric } \\
& \text { hydrogen generation } \\
& C=\frac{n}{V}=\frac{P}{R T} \\
& \text { rate. } \\
& -\frac{P}{R T} X_{\text {part }} V_{0}+\frac{P}{R T} \frac{d V_{A}}{d t}=V_{b} \frac{P}{R T} \frac{d X_{A}}{d t} \\
& \frac{d x_{A}}{d t}+\frac{V_{0}}{V_{b}} x_{A}=\frac{\frac{d V_{A}}{d t}}{V_{b}}
\end{aligned}
$$


OR $25-10<\operatorname{Rev} 6-18-92)$

ENGINEERING COMPUTATION SHEET SRNL-STI $-2011-\infty 364$

C-Reactor Disassembly Basin $\mathrm{H}_{2}$

Project No.

P. Al -12

SiS

Subject

Computer B.J. Wiersma Date $7 / 6 / 1$

Sheet No. II

- $\frac{d V_{A}}{d t}$ changes with time due to passivation of aluminum

- Assume $\frac{d V_{A}}{d t}$ is constant. Assume the rate is equal to the hydrogen. generated in one day divided by the hours in a day.

- From reference 4
$\frac{d V_{A}}{d t}=\frac{\int_{0}^{t} Q_{H_{2}}^{\prime} e^{-2.31 t} d t}{\Delta t}$

$Q_{H_{12}}^{\prime}=$ Volumetric $H_{2}$ generation rate per unit Area $t=$ time in how

$$
\begin{aligned}
\frac{d V_{A}}{d t} & =-\left.\frac{Q_{H_{2}}^{\prime}}{2.31}\left[e^{-2.31 t}\right]\right|_{0} ^{24} \\
& =\frac{Q_{H}^{\prime}}{2.31(24)}\left[1-e^{-2.31(24)}\right] \\
& =-\frac{Q_{H_{C}}^{\prime}}{55.4^{\prime}}
\end{aligned}
$$

In order to obtain a volumetric flow rate $Q_{H_{2}}^{\prime}$ must be multiplied by the surface cred of aluminum reacting. As a conservative estimate it will be assumed that all the aluminum in the basin is reacting. Reference 2 indicates that this is $A_{A_{1}}=11,572 \mathrm{ft}^{2}$.

$$
R_{A}^{\prime}=\frac{d V_{A}}{d t}=\frac{Q_{A_{2}}^{\prime}}{55.4} * A_{A_{1}}=209 * Q_{H_{2}}^{\prime}
$$


OSR $25 \cdot 10(\operatorname{Rev} 6-18-92)$

$$
\text { SRNL-STI-2011-00364 }
$$

ENGINEERING COMPUTATION SHEET P. $A 1-13$

Title of Project C-Reactor Disassembly Basin $\mathrm{H}_{2}$ Project No.

Subject Works Computer B.J. Wiersma

Date $7 / 6 / 11$ Sheet No. $/ 2$

For $\mathrm{Ca}(\mathrm{OH})_{2}$ the highest $Q_{\mathrm{H}_{2}}^{\prime}$ could occur in the horizontal tube storage area where the temperature could rise to $62{ }^{\circ} \mathrm{C} . Q_{\mathrm{A}_{2}}^{\prime}=2.85 \times 10^{-5} \frac{\mathrm{m}^{3}}{\mathrm{~m}^{2}-\mathrm{s}}$ from the table on sheet 3 .

For grout at a' temperature of $50^{\circ} \mathrm{C}, Q_{\mathrm{H}_{2}}^{\prime}=3.69 \times 10^{-6} \mathrm{~m}^{3}$ Solve initial value problem

$$
\begin{gathered}
\frac{d x_{A}}{d t}+\frac{V_{0}}{V_{b}} x_{A}=\frac{R_{A}^{\prime}}{V_{b}} \\
x_{A}=0 \quad a^{+} \quad t=0 \\
x_{A}=\frac{R_{A}^{\prime}}{V_{0}}\left(-e^{\left(-t v_{0} / V_{b}\right)}\right)
\end{gathered}
$$

$V_{b}=$ Volume of vapor space above basin

Cross-sectiona/ Area per drawing W/34454

$$
203,25 \text { feet } \times 130 \text { feet }=26,423 \mathrm{ft}^{2}
$$

Height $=$ no feet above the water level of the basin

$$
Y V_{b}=528,450 \mathrm{ft}^{3}
$$

- Determine $\quad X_{A}$ as a function of $v_{0}$.

- Go l is to keep $x_{A}$ less the 60\% of the LFL. 
SRNL-STT-2011-00364

\section{APPENDIX 2}

Page A2-1 


$$
\begin{array}{r}
S R N L-S T I-2011-00364 \\
\text { P. } A 2-2
\end{array}
$$

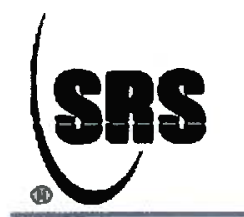

History:
Re: 105-C D\&E Canal in Process Room

William Griffin to: Bruce Wiersma

John Blankenship, John Musall, Michael Serrato, Christine

Langton, Kristine Zeigler, Brenda Garcia-Diaz

06/22/2011 04:34 PM

See comments in red below; slight variation to yours.

Bill Griffin

D\&D Engineer

Office 803-952-6449

Cell 803-761-1338

Pager 31164

Bruce Wiersma

Bill, I thought I would write an e-mail to verify our...

06/22/2011 12:18:59 PM

From: $\quad$ Bruce Wiersma/SRNL/Srs

To: William Griffin/SRNS/Srs@Srs

Cc: John Blankenship/SRNS/Srs@Srs, John Musall/SRNS/Srs@Srs, Michael Serrato/SRNL/Srs@Srs, Christine Langton/SRNL/Srs@Srs, Kristine Zeigler/SRNL/Srs@Srs, Brenda

Date: $\quad$ Garcia-Diaz/SRNLSrs

Subject: Re: $105-C$ D\&E Canal in Process Room

Bill,

I thought I would write an e-mail to verify our discussions from yesterday. We were trying to determine a representative local area for the analysis. That is what is the cross-sectional area of the basin that should be considered for the analysis. I have summarized what we said by referring to coordinates that appear on drawing $\mathrm{W} 134454$.

Vertical Tube Storage: AR to $O$ by 101 to 102 ; Control Rods contribute to majority of aluminum surface area. Agree

Machine Basin: AR to $O$ and 106 to 108 ; Septifoil and Safety Rod Thimble contribute to majority of aluminum surface area. $10^{\prime}$ south of AR to $O$ by 105 to 108

Horizontal Tube Storage: AL to 18 feet north of AL by 101 to 107; Racks with USH's contributes to the majority of the surface area. AL to $20^{\prime}$ north of AL by 101 to 107

Dry Caves: 28.5 feet by 102 to 103; USH's present. 30' by 102 to 103

D\&E Canal: 64 feet by 4 feet; We had agreed on this previously. Agree

If you could let me know if you agree with this.

Thanks,

Bruce J. Wiersma

Savannah River National Laboratory

Materials Science and Technology

Bldg. 773-A, Rm. D-1125

Phone: 725-5439

FAX: 725-7369

e-mail: bruce.wiersma@srnl.doe.gov

William Griffin

Bruce Wiersma

William Griffin i just sent you a copy. Bill Griffin

Bill, Thanks for the photos. I was looking for the...

Photos for your use and info. Bill Griffin
05/23/2011 04:29:11 PM

05/23/2011 04:23:46 PM

05/23/2011 04:18:56 PM 